Moose on the Loose: Indigenous Men, Violence, and the Colonial Excuse (with errata)

\author{
Robert Alexander Innes \\ Department of Native Studies, University of Saskatchewan
}

aboriginal policy studies Vol. 4, no. 1, 2015, pp. 46-56

This article can be found at:

http://ejournals.library.ualberta.ca/index.php/aps/article/view/24193

ISSN: $1923-3299$

Article DOI: http://dx.doi.org/10.5663/aps.v4i1.24193

aboriginal policy studies is an online, peer-reviewed and multidisciplinary journal that publishes original, scholarly, and policy-relevant research on issues relevant to Métis, non-status Indians and urban Aboriginal people in Canada. For more information, please contact us at apsjournal@ualberta.ca or visit our website at www.ualberta.ca/nativestudies/aps/. 


\title{
Moose on the Loose: Indigenous Men, Violence, and the Colonial Excuse (with errata)
}

\author{
Robert Alexander Innes \\ Department of Native Studies, University of Saskatchewan
}

At a time when there has been increasing pressure on the federal government to launch a national inquiry into murdered and missing Indigenous women, a number of editorials and commentaries have appeared in various media outlets and blogs discussing Indigenous men's attitudes toward Indigenous women. For example, Bernard Valcourt, currently Minister of Aboriginal Affairs and Northern Development Canada (AANDC), stated that "if we're honest here," it is obvious that "there's a lack of respect for women and girls on reserves... So, you know, if the guys grow up [on the reserve] believing that women have no rights, that's how they are treated." 1 The following day, Ojibwe lawyer Joan Jack, who strongly supports a national inquiry, stated that "Aboriginal men kill aboriginal women and girls, rape aboriginal women and girls, beat aboriginal women and girls, and no one is really talking about the moose in our living room."' The Globe and Mail noted Assembly of First Nations National Chief Perry Bellegarde, a strong advocate for a national inquiry, as asserting that, "Aboriginal men must address deep-seated issues stemming from the Indian Residential School system, including addiction and cycles of violence," implying a link between violence against Indigenous women and Indigenous men. ${ }^{3}$ These types of comments point to Indigenous men as the cause of the violence that Indigenous women face, and stress that if Indigenous men acknowledge and address the physical and sexual harm they inflict on Indigenous women, then the level of violence those women endure will decrease greatly. The assertion, made explicitly by Valcourt and others, is that since Indigenous men are implicated as the main perpetrators of gender-based violence against Indigenous women, there is no need for a national inquiry.

Although Valcourt's and Jack's comments are not necessarily inconsistent with the data that suggest the majority and perhaps even the overwhelming majority of acts of violence against Indigenous women are committed by Indigenous men, they fail to acknowledge

1 Mark Kennedy, "Valcourt urges First Nations, Provinces to Take Action on Murdered Aboriginal Women," Ottawa Citizen Online, December 12, 2014, accessed December, 12. 2014, http://ottawacitizen.com/news/ politics/bernard-valcourt-rejects-inquiry-on-murdered-aboriginal-women.

2 Joan Jack, "Excuse Me, There's a Moose in the Living Room," Winnipeg Free Press Online, December 13, 2014, accessed December 13, 2004 http://www.winnipegfreepress.com/opinion/analysis/aboriginal-womenfear-their-own-kind-the-most-285701831.html.

3 It should be noted these are the reporter's words and not a direct quote from Bellegarde. Kathryn Blaze Carlson, "AFN Chief Urges Native Men to Help Protect Women," Globe and Mail Online, February 2, 2015, accessed February 3, 2015, http://www.theglobeandmail.com/news/national/aboriginal-leader-urges-nativemen-to-help-protect-women-in-community/article22755092/.

aboriginal policy studies, vol. 4, no. 1, 2015

www.ualberta.ca/nativestudies/aps/

ISSN: $1923-3299$ 
1) the level of violence against Indigenous men, which, according to some reports, occurs at a much higher level than that against Indigenous women; 2) the unique ways in which Indigenous men experience violence; or 3) the context in which the violence is manifested. These comments serve to deflect any culpability regarding the current state of Indigenous communities from the government onto those communities, and more specifically onto Indigenous men. The government has made it clear that it does not want to conduct an inquiry into murdered and missing Indigenous women, but has not provided a compelling reason to justify its position, other than Prime Minister Harper's unfounded assertion that murdered and missing Indigenous women do not represent a sociological phenomenon but simply individual criminal acts and his remark that an inquiry "isn't really high on our radar, to be honest." Significantly, these comments fail to situate Indigenous male violence within the context of the imposition of the White supremacist heteronormative patriarchy internalized through the colonial process. The resulting tribal patriarchy is sustained by, among other means, violence directed towards Indigenous children, women, Elders, and men. Within this setting it becomes clear that one of the government's strategies to derail momentum for a national inquiry is to use the racial and gender biases evident in Canadian society against Indigenous men to blame them for the violence, while eschewing any responsibility for creating and maintaining the conditions that channel many Indigenous men into situations of despair, dysfunction, and violence.

\section{Setting the Moose Loose}

Joan Jack was correct when she stated that many Indigenous people do not like to discuss the issue of violence associated with Indigenous men. For many, this kind of discussion reinforces negative stereotypes attached to Indigenous men. Others believe that focusing on violence committed by Indigenous men wrongly shifts attention to them and away from the violence white men inflict on Indigenous women, while others see it as a means of relieving the government of its responsibility. However, an examination of the available statistics underscores the level of violence in which Indigenous men are involved, and makes very apparent the fact that Indigenous men's experiences with violence have not been fully acknowledged, articulated, understood in any significant way.

Table 1 below shows that there are 163,000 Canadians in the correctional system, over 37,000 of whom are incarcerated. Of the incarcerated, 89 percent or 33,376 are males, and 11 percent or 4,123 are females. In December of 2014, news reports highlighted the dramatic increase in the incarceration rate for Indigenous women. ${ }^{4}$ The report notes that the incarceration rates for Indigenous women have nearly doubled in 10 years, but by "comparison, the number of aboriginal men increased by a comparatively small 34 per

4 CBC News, "Aboriginal Women One-Third of All Female Prisoners: Report: Federal Incarceration Rates for Aboriginal Women up 84 Per Cent in the last 10 years," CBC News Online, December 2, 2014, accessed, December 2, 2104, http://www.cbc.ca/news/canada/north/aboriginal-women-one-third-of-all-femaleprisoners-report-1.2448337; Steve Rennie, "Huge Increase in Number of Aboriginal Women in Canadian Prisons," Toronto Star, December 2, 2014, accessed December 2 2014, http://www.thestar.com/news/ canada/2014/12/02/huge_increase_in_number_of_aboriginal_women_in_canadian_prisons.html. 
cent during that time." ${ }^{5}$ Though the increase in Indigenous women's incarceration rate is alarming, this trend was known a decade ago, according to Toni Williams. ${ }^{6}$ The news report, however, did not provide hard figures for incarcerated Indigenous women and men to place the increase in better context.

In her 2012 report for the Canadian Centre for Justice Studies, Mia Dauvergne noted that Indigenous women comprised 41 percent (1,690 in total) of all females incarcerated in 2010/2011, while Indigenous males represented 23 percent or 7,674 of all males incarcerated. Using Dauvergne's figures to calculate these numbers, then, Indigenous women represented 4.5 percent of the total incarcerated population and Indigenous men represented 20 percent (See Table 1). If the incarceration rate for Indigenous women continues to increase at the same pace, in 10 years there will be 3,380 who are incarcerated, and this number could reach 6,760 by 2030 . If the incarceration rate for Indigenous men increase by 34 percent again in the next 10 years, there could be over 10,000 Indigenous men in prison by then, and close to 14,000 in 2030 , for a combined Indigenous inmate population of close to 20,000 by $2030 .^{7}$

\section{TABLE $1^{8}$}

\begin{tabular}{|c|c|c|c|c|c|c|}
\hline $\begin{array}{l}\text { Total People in } \\
\text { Corrections System }\end{array}$ & & 163,000 & & & & \\
\hline $\begin{array}{l}\text { In Community (i.e., on } \\
\text { probation, etc.) }\end{array}$ & $77 \%$ & $125,510^{*}$ & & & & \\
\hline Total Incarcerated & $23 \%$ & $37490^{*}$ & $\begin{array}{l}\text { Total Indigenous } \\
\text { Incarcerated }\end{array}$ & $9,364^{*}$ & & $\begin{array}{l}25 \%{ }^{*} \text { of total } \\
\text { incarcerated }\end{array}$ \\
\hline $\begin{array}{l}\text { Number of Males } \\
\text { Incarcerated }\end{array}$ & $89 \%$ & $33,367^{*}$ & $\begin{array}{l}\text { Number of Indigenous } \\
\text { Males Incarcerated }\end{array}$ & $7,674^{*}$ & $\begin{array}{l}23 \% \text { of male } \\
\text { incarcerated }\end{array}$ & $\begin{array}{l}20 \%{ }^{*} \text { of total } \\
\text { incarcerated }\end{array}$ \\
\hline $\begin{array}{l}\text { Number of Females } \\
\text { Incarcerated }\end{array}$ & $11 \%$ & $4,123^{*}$ & $\begin{array}{l}\text { Number of Indigenous } \\
\text { Females Incarcerated }\end{array}$ & $1,690^{*}$ & $\begin{array}{l}41 \% \text { of female } \\
\text { incarcerated }\end{array}$ & $\begin{array}{l}4.5 \%{ }^{*} \text { of total } \\
\text { incarcerated }\end{array}$ \\
\hline
\end{tabular}

Source: Adult Correctional Statistics in Canada, 2010/2011

The hard number of homicides involving Indigenous men is not well-documented in the media or in academic circles. The RCMP recently released their report on missing and murdered Indigenous women, and shocked the country by noting that 1,017 Indigenous

5 Rennie, "Huge Increase."

6 Toni Williams, "Punishing Women: The Promise and Perils of Contextualized Sentencing for Aboriginal Women in Canada," Cleveland State Law Review 55, no. 3 (2007): 279

7 Of course it is difficult to provide accurate projections, as these figures may not indicate the trend of the increases.

8 Mia Dauvergne in her report, Adult Correctional Statistics in Canada, 2010/2011 (Ottawa: Canadian Centre for Justice Statistics, 2012). 
women were murdered between 1980 and 2012. In addition, the report showed that over 90 percent of the murdered victims knew their murderer and that nearly 90 percent of the murderers were male. The RCMP has stated that it does not have any plans to conduct a similar report on Indigenous men. Though the homicide data pertaining specifically to Indigenous men are not easily accessible, cobbling together data from census and news reports allows us a glimpse into the magnitude of the situation.

According the Statistics Canada's Homicide Survey, between 1997 and 2000, the most recent census data I could find, Indigenous men in Canada were victims of homicide at nearly 2.5 times the rate of Indigenous women, almost seven times the rate of white men, and over fifteen times that of white women. ${ }^{9}$ A 2006 Census Canada report that looked at the homicides of Indigenous women and men showed that between 1997 and 2004 there were 329 Indigenous men murdered, compared to 141 Indigenous women. Further to this, and also according Statistics Canada's Homicide Survey, between 1997 and 2000, Indigenous men were charged with homicide over four times more often than Indigenous women, almost nine times more than non-Indigenous men, and nearly ninety times more than white women. ${ }^{10}$ Taken together with the fact that, according to the RCMP report, over 90 percent of Indigenous women knew their murderers, it is highly probable that Indigenous men murder the majority, or at least a large number, of Indigenous women murder victims. ${ }^{11}$

Though murder statistics regarding Indigenous men are also difficult to obtain, some recently published statistics shed some light. For example, Maryanne Pearce, a doctoral student at the University of Ottawa, found that 824 Indigenous men have been missing or murdered since at least the 1950s. ${ }^{12}$ In May 2014, Vice Online published a story outlining the work of Jen Mt. Pleasant, who has been searching various online databases for information about missing and murdered Indigenous men. ${ }^{13}$ Her research found that over 600 Indigenous men have gone missing or been murdered since the 1950s. In August 2014, the Toronto Star published a story asserting that Indigenous men are murdered at a higher rate than Indigenous women. The story cited Statistics Canada data that between 1980

9 Jodi-Anne Brzozowski, Andrea Taylor-Butts, and Sara Johnson, "Victimization and Offending Among the Aboriginal Population in Canada," Canadian Centre for Justice Studies, Statistics Canada - Catalogue no. 85002-XIE, Vol. 26, no. 3 (2006): 7

10 Brzozowski et al., 8

11 Canada, "Missing and Murdered Aboriginal Women: A National Overview" (Ottawa: RMCP, 2014), 12.

12 Maryanne Pearce, "An Awkward Silence: Missing and Murdered Vulnerable Women and the Canadian Justice System” (LL.D. dissertation, University of Ottawa: Ottawa, 2013).

13 Martha Troian, "An Independent Database Has Found Canada Lost over 600 Missing or Murdered Aboriginal Men," Vice Online, May 20, 2014, accessed May 21, 2014, http://www.vice.com/en_ca/read/anindependent-database-has-concluded-canada-has-lost-over-600-missing-or-murdered-aboriginal-men. 
and 2012, 745 Indigenous women and 1,750 Indigenous men were victims of murder. ${ }^{14}$ It is significant to note that Statistics Canada, in light of the RCMP report on missing and murdered Indigenous women, acknowledged that its data were not up to date, and stated, "Statistics Canada is working with the RCMP and other police services to update its database with the supplementary data the RCMP used for the report and to continue to receive this data for subsequent years." ${ }^{15}$ Considering that the Statistics Canada records show 745 murdered Indigenous women and the RCMP report shows 1,017, it is conceivable that the number of murdered Indigenous men could be closer to 2,000 for the years between 1980 and 2012, which would mean that a total of over 3,000 Indigenous people were murdered during that time period.

\section{TABLE 2}

\begin{tabular}{|c|c|}
\hline Murders & Numbers \\
\hline Total murders in Canada in $2013^{1}$ & 505 \\
\hline Percentage of murders committed by men ${ }^{2}$ & $88 \%$ \\
\hline Percentage of male victims ${ }^{3}$ & $71 \%$ \\
\hline Total number of male victims ${ }^{4}$ & 358 \\
\hline Number of Indigenous women murdered 1980-2012 (Census) ${ }^{5}$ & 745 \\
\hline Number of Indigenous women murdered 1980-2012 (RCMP Report) ${ }^{6}$ & 1017 \\
\hline Percentage of murders committed by men ${ }^{7}$ & $89 \%$ \\
\hline Number of Indigenous men murdered 1980-2012 (Census) ${ }^{8}$ & 1750 \\
\hline Total number of Indigenous murder victims (estimate) & 2,767 \\
\hline Percentage of Indigenous male victims (estimate) & $63 \%$ \\
\hline
\end{tabular}

Source: Various. ${ }^{16}$

14 Eric Andrew-Gee, "Aboriginal Men Murdered at Higher Rate Than Aboriginal Women," Toronto Star Online, August 22, 2014, accessed September 22, 2014, http://www.thestar.com/news/gta/2014/08/22/ aboriginal_men_murdered_at_higher_rate_than_aboriginal_women.html.

15 Adam Cotter, "Homicide in Canada, 2013" (Ottawa: Canadian Centre for Justice Statistics, Statistics Canada, 2014), 17.

16 (1) Cotter, "Homicide in Canada, 2013," 4. (2) Ibid., 15. (3) Ibid., 15. (4) Ibid., 33. (5) Andrew-Gee, "Aboriginal Men Murdered." (6) Canada, "Missing and Murdered," 7. (7) Ibid., 13. (8) Andrew-Gee, "Aboriginal Men Murdered." 
Although far from definitive, the data shows that Indigenous men are much more likely to commit, be charged with, and die as a result of murder than anyone else in Canada. They are also more likely than anyone else to be incarcerated. Joan Jack is correct in referring to these facts as the moose in the living room insofar as few are willing to discuss the high rate of violence in which Indigenous men are implicated. However, even fewer discuss the level of violence inflicted upon Indigenous men. In many ways, this is not surprising; as I will argue next, placing the emphasis on the violence of which Indigenous men are capable while at the same time ignoring their victimization is caused by a specific kind of race and gender bias many white people have towards Indigenous men.

\section{Understanding Indigenous Male Violence}

From the federal government's perspective, the evidence of the prevalence of violence among Indigenous men supports its contention that a national inquiry into murder and missing Indigenous women is unnecessary - the problem, according to government, is Indigenous men themselves. This view of Indigenous men only as victimizers acts to simplify a long history of complex colonial interaction between Indigenous people and Canadians. Indigenous people underwent an intense process of cultural genocide through federal and provincial governments' formal assimilation policies and through everyday informal interactions with white people. The assimilation process used and continues to use the White supremacist heteronormative patriarchy as a means of colonizing Indigenous peoples' bodies, minds, and lands, leaving a lasting and negative impact on Indigenous communities.

For Indigenous men, the assimilation process meant, among other things, that Indigenous ideals of masculinity had to be replaced to conform to a masculinity that upheld the White supremacist heteronormative patriarchy. ${ }^{17} \mathrm{~A}$ certain kind of hierarchy supports this patriarchy. Where someone is situated in the hierarchy is determined in relation to males who exhibit a combination of the masculine attributes informed by White supremacist heteronormative patriarchy. The notions of this masculinity are what all men must strive to achieve and maintain in order to be recipients of male privilege to its fullest extent. Indigenous men, like all men, benefit from male privilege. Not all men receive the same level of benefits, however; as Connell states, "the men who receive most of the benefits and the men who pay most of the costs are not the same individuals." ${ }^{18}$ Benefits

17 An example of the way in which White supremacist heteronormative patriarchy acts to oppress women and people of colour is seen in pay inequity in Canada. See Sheila Block, "Ontario's Growing Gap: The Role of Race and Gender" (Ottawa: Canadian Centre for Policy Alternatives, 2010). Also, the level of the violence women, people of colour, lesbians, bisexuals, gays, and trans men and women face is another outcome of this patriarchy. For examples of the level of violence against LBGTQ community, see National Coalition of AntiViolence Programs, "Lesbian, Gay, Bisexual, Transgender, Queer, and HIV-Affected Hate Violence in 2013," (New York, 2014).

18 Raewyn Connell, "Change Among the Gatekeepers: Men, Masculinities, and Gender Equality in the Global Arena," Signs: Journal of Women in Culture and Society 30, no. 3 (2005): 1809. 
of male privilege that arise out of the White supremacist heteronormative patriarchy are based on multiple intersecting factors that depend on race, sexuality, class, and physical and mental attributes, among other considerations. Both men and women understand what the current masculine ideals are, as these ideals are ubiquitous, making it very difficult for alternative forms of masculinity to exist equally in our society. The hegemonic nature of current masculine ideals has been normalized, and as a result, most uncritically accept the male behaviours it engenders as simply "the way things are."

The racialized and gendered perceptions that white people have of Indigenous men situate the latter within the hierarchy in a subordinate position to white men. Recognizing how race and gender bias intersect to disadvantage Indigenous men can assist our understanding of the nature of violence involving Indigenous men, and can also explain how viewing them as victimizers is relatively easy for white people. Khaled Beydoun is helpful here, as he outlines the intersectionality of race and gender bias men of colour in the United States face. ${ }^{19}$ According to Beydoun, men of colour in the U. S. face not only racial discrimination but gendered discrimination as well, although these two forms of discrimination are seldom discussed together in relation to men. Beydoun notes that "The distinct tropes associated with black and brown masculinity ... attract a distinct brand of gendered racism reserved for men of colour. Indeed, being both minority and male in the US today invites a brand of gendered stigma that is under-discussed in media and academic circles, and marginalised by a narrow conception of gender discrimination. ${ }^{20}$

Men of colour do not face the same kind of gender and race bias women of colour face. Nevertheless, Beydoun forces us to consider the way in which gender discrimination works in concert with racial discrimination to oppress men of colour, and makes us think about ways to include gender analysis when examining the experiences of Indigenous men. As Beydoun concludes, "the pervasive forms of gendered bias and violence that are specifically reserved for men of colour, in the streets of the US, within its halls of power, and its public and private institutions, must be figured into prevailing conceptions of gender discrimination." ${ }^{21}$ Certainly this can be seen in the number of police shootings involving African American men that have garnered much attention in the U.S over the past 12 months. In the Canadian context, a significant outcome of race and gender bias is seen in the way the media, politicians, and therefore many Canadians view Indigenous men exclusively as victimizers. The fact that many are also victims is rendered inconsequential.

Another consequence of race and gender bias towards men of colour is the perception that white women are in constant danger of succumbing to violence at their hands, even though white women are the least likely to experience violence of any group. As the data above

19 Khaled Beydoun, "More Than Thugs: The Case of Richard Sherman and Other Men of Colour," Al Jazeera Online, January 29, 2014, accessed January 30, 2014, http://www.aljazeera.com/indepth/opinion/2014/01/ more-than-thugsthe-case-richar-2014125134532950282.html. Emphasis in original.

20 Ibid.

21 Ibid. 
indicates, white women are the least likely to be murdered or go missing. (In Saskatchewan, for example, white women are numerically the largest group in the province, but are by far the least likely to go missing. ${ }^{22}$ ) White people's negative perceptions of Indigenous men lead them to fear them. Fear of "minority masculinities" is rooted in and is a counterpoint to hegemonic white hetropatriarchal masculinity:

The black and brown bodies of men of colour incite an overwhelming fear for onlookers, whether politicians, policemen, or television viewers, who interpret their minority masculinity as threatening and deviant. Terrorists instead of American citizens, gang-members not undergraduates, and dreadlocked thugs instead of Stanford graduates - is the confined view of black and brown men that still prevails today. This in part, must be attributed to the confined discourse and definition of gender discrimination. ${ }^{23}$

The amount of news coverage white women's victimization garners in comparison to that of Indigenous women fuels these fears. ${ }^{24}$

White peoples' fear influences how they respond to Indigenous men's presence, whether through institutions or media, or in face-to-face interactions. This fear compels many white men to want to protect themselves and white women from Indigenous men. The interaction between white male police officers and Indigenous males is an example not only of the way in which the White supremacist heteronormative patriarchal hierarchy is protected but also of the way in which negative treatment of Indigenous men is justified and accepted because of their supposedly violent and dangerous nature. ${ }^{25}$

As a result of assimilation efforts, many Indigenous men have, to varying degrees, internalized White supremacist heteronormative masculine ideals and have, also to varying degrees, adapted it to a tribal patriarchy within their communities. ${ }^{26}$ As non-

22 The Saskatchewan Association of Police Chiefs' website provides statistics for missing persons in the province; between 1940 and 2014, 15 white women had gone missing, compared to 50 white men, 38 Indigenous men, and 18 Indigenous women. Indigenous men are numerically the smallest of these subpopulations in Saskatchewan. See https://www.sacp.ca/missing/index.php.

23 Beydoun, "More Than Thugs." Emphasis in original.

24 See for example Kristen Gilchrist, “'Newsworthy Victims?': Exploring Differences in Canadian Local Press Coverage of Missing/Murdered Aboriginal and White Women," Feminist Media Studies 10, no. 4 (2010): 1-23

25 For example, see Canadian Press, "Alberta RCMP Shoot, Kill Man After Road Stop Altercation," National Post Online, August 4, 2013, accessed August 20, 2013,

http://news.nationalpost.com/2013/08/04/alberta-rcmp-shoot-kill-man-after-road-stop-altercation/. See also Sherene Razack, "It Happened More Than Once': Freezing Deaths in Saskatchewan," Canadian Journal of Women and the Law 26, no. 1 (2014): 51-80.

26 Brendan Hokowhitu, in a forthcoming article, outlines the emergence of tribal patriarchies (though he does not use this exact term) within Indigenous communities: "Productive heterosexual patriarchy became the model, the norm - the post-contact tradition, reflecting invader culture, yet also reproducing the focus of Indigenous cultures on genealogical lineage." Brendan Hokowhitu, "Taxonomies of Indigeneity: Indigenous Heterosexual Patriarchal Masculinity," in Indigenous Men and Masculinities: Legacies, Identities, Regeneration, eds. Kim Anderson and Robert Alexander Innes (Winnipeg: University of Manitoba Press, forthcoming). 
whites, Indigenous men's privilege is ultimately subordinate to (and subordinated by) white male privilege, and therefore at some point these men are unable to proceed up the hierarchy. However, the ways in which the White supremacist heteronormative patriarchy subordinates Indigenous men also provide some with a mechanism, through existing tribal patriarchies, by which to subordinate Indigenous women and other Indigenous men who are considered physically and/or intellectually weak, as well as those who do not express a heteronormative identity. Therefore, many Indigenous men abide by White masculine ideals, even though their actions, or even their perceived actions, ironically reinforce stereotypes and contribute to the subordination of Indigenous men as a group, thereby supporting the colonial structures that oppress all Indigenous peoples.

Though the quote from the Globe and Mail in the opening paragraph of this commentary suggests that Chief Bellegarde is linking violence against Indigenous women to that perpetrated by Indigenous men, the link that Bellegarde is actually making is not that men are perpetrating the violence, but rather that, due to the colonial process, they are not protecting women from violence. He urges Indigenous men to learn the traditional family teachings that "will guide you in your life on how you deal with yourself, your spouse and your family" so that these men will then fulfill their roles as protectors. ${ }^{27}$ Though Bellegarde does not explicitly acknowledge the possibility of Indigenous male violence towards women, what he does acknowledge, unlike others, is the impact of forced assimilation policies on men, and the fact that these experiences have had negative repercussions for Indigenous communities.

The Indigenous community and the country as a whole must come to grips with the level of violence involving Indigenous men. In other words, to borrow Joan Jack's phrasing, "the moose has to be let loose" on the subject of Indigenous male violence. However, it is also important to note that even though many Indigenous men are entangled in dysfunctional and violent situations, the majority is not. More and more Indigenous men like Paul Lacerte, who created the Moose Hide Campaign, are publically and actively taking a stance against violence towards Indigenous women. ${ }^{28}$ Indigenous male violence does not occur in a vacuum. Violence, contrary to the racial and gender perceptions Canadians have, is not a natural outcome of the Indigenous male psyche.

\section{Policy Options}

If government actors are truly interested in assisting Indigenous communities in dealing with the violence in their communities, they should demonstrate this commitment by developing a national strategy to curb violence against Indigenous women. Special attention should be paid to the way race, gender, and power intersect in the violence faced by Indigenous

27 Carlson, "AFN Chief Urges."

28 Joanne Smith, "Moose Hide Campaign Helps Men Address Violence against Aboriginal Women," Toronto Star Online, December 31, 2014, accessed December 31, 2014, http://www.thestar.com/news/ canada/2014/12/31/moose_hide_campaign_helps_men_address_violence_against_aboriginal_women. html. 
women. To address violence against Indigenous women successfully, a strategy should also address Indigenous men both as victimizers and as victims. There are two approaches the federal government can chose in working towards a plan. It can either launch a national inquiry into the matter of Indigenous violence that leads to recommendations for a national strategy, or it can develop a national strategy without an inquiry. No matter which path government takes, it should restore funding to Indigenous social organizations that deal with violence against women. A national inquiry must take as its basis that violence experienced by Indigenous women is a result of colonialism based on White supremacist heteronormative patriarchy, and should allow as many people as possible to recount their experiences and give input on possible strategies. The Canadian federal government could, however, develop a national strategy based on existing information from scholarly work, government and social agency reports, and recommendations from previously held inquests, inquiries, and reports, ${ }^{29}$ and could still allow extensive feedback from Indigenous social and political organizations. This approach would give policymakers the ability to fast-track solutions. Whichever approach government selects, it needs to be prepared to provide the necessary funding to ensure success.

Whether or not a national inquiry is the route to take is an important discussion to have. It is clear, however, that this is not a discussion in which the federal government wants to engage, as Bernard Valcourt has made clear: "[A] national inquiry is an excuse for not taking action." 30 That, of course, would only be the case if the government failed to implement any recommendations that might result from an inquiry. Instead of an inquiry, Valcourt states that government wants to work with local communities, but he is vague on details. Most Indigenous communities would like to have the capacity to develop strategies and implement real solutions. That government has consistently cut funding to Indigenous organizations that deal directly with issues of violence against Indigenous women leaves many with little confidence that the government will provide the necessary funding for this. ${ }^{31}$ Meanwhile, the Harper government has explicitly stated that it will increase funding to establish more prisons, which will no doubt accommodate the increased Indigenous population that will surely be the result of government inaction in addressing this matter. ${ }^{32}$

29 The most recent report was just released in December 2014: Inter-American Commission on Human Rights, "Missing and Murdered Indigenous Women in British Columbia, Canada" (Organization of American States, OEA/Ser. L/V/II. Doc.30/14, 2014).

30 John Geddes, "Bernard Valcourt: A Street Fighter Heads Back to the Streets," Macleans, January 6, 2015, accessed January 6, 2015, http://www.macleans.ca/politics/ottawa/bernard-valcourt-a-street-fighter-headsback-to-the-streets/.

31 For a funding-cut timeline for the Native Women's Association of Canada's Sisters in Spirit initiative and other Indigenous women's organizations, see Voices-Voix Online, "Sisters in Spirit," http://voices-voix.ca/en/ facts/profile/sisters-spirit.

32 Jim Bronskill, "Critics Say Harper Government Throwing Prison Expansion Money Away," Toronto Star Online, January 11, 2011, accessed December 13, 2014, http://www.thestar.com/news/canada/2011/01/10/ critics_say_harper_government_throwing_prison_expansion_money_away.html. 
Asserting that an inquiry is not needed by simply blaming Indigenous men for the violence suffered by Indigenous women not only treats inquiries merely as criminal investigations, it also plays into many Canadians' racial and gender biases and ignores the colonial role the Canadian government and Canadians have played in creating the situation; it is therefore little more than a colonial excuse that allows government to shirk its legal and ethical responsibility to Indigenous people in Canada. 


\section{ERRATA}

\section{Moose on the Loose: Indigenous Men, Violence, and the Colonial Excuse}

Robert Alexander Innes

Department of Native Studies, University of Saskatchewan

The article stated that (on page 49), "Maryanne Pearce, a doctoral student at the University of Ottawa, found that 834 Indigenous men have been missing or murdered since at least the 1950s." This is incorrect. Pearce's dissertation found that 824 Indigenous women had been missing or murdered.

aboriginal policy studies, vol. 4, no. 1, 2015

www.ualberta.ca/nativestudies/aps/

ISSN: $1923-3299$ 